\begin{tabular}{|lll|}
\hline & Uniqbu Journal of Social Sciences (UJSS) \\
\hline Volume: 2 & Nomor 1, April 2021 & Halaman 54-61 \\
\hline
\end{tabular}

\title{
CLASSROOM ACTION MANAGEMENT RELATIONSHIP TOWARD INDONESIAN LEARNING OUTCOMES
}

\author{
(Hubungan Manajemen Tindakan Kelas Terhadap Hasil Belajar Bahasa Indonesia)
}

\author{
Muhammad Yusnan and Wulandari \\ University Muhammadiyah Buton \\ Email: muhammadyusnan@gmail.com \\ wualandari@gmail.com
}

(Received 10 February; Revised 28 February; Accepted 02 March 2021)

\begin{abstract}
Improving the quality of education will be achieved if the teaching and learning process by the teacher held in the classroom is truly effective and useful for achieving the expected knowledge, attitudes, and skills. Because basically, the teaching and learning process is the core of the overall education process, while the teaching and learning process is carried out in many formal activities in the classroom where the teacher is one of the important factors in determining the success of the teaching and learning process in the classroom. Therefore teachers are required to be able to improve their roles and competencies, competent teachers will be more able to create an effective learning environment and will be more capable of Classroom Action Management so that student learning outcomes are at an optimal level. The purpose of this study was to determine the effect of classroom action management on Indonesian learning outcomes, the subject of story listening skills in SD Negeri 1 Kaobula. The method used in this research is quantitative descriptive which is used as a research design that clearly and clearly describes the research variables in the form of numbers and statistics. The population of this research is the fifth-grade students of SD Negeri 1 Kaobula which consists of 24 students. Based on the results of the study, it is concluded that the influence between the X variable (classroom action management) and the $Y$ variable (Civics learning outcomes) has a strong influence between the two variables. If we look at the amount of oxy obtained, namely: 0, 620 it turns out to be between 0.40. 0.60. It can be stated that the correlation between variable $X$ and variable $Y$ is a relatively strong influence. Thus, the authors can simply give an interpretation of the oxy, namely that there is a significant positive effect between variable $X$ and variable $Y$.
\end{abstract}

Keywords: Education, Kemuhammadiyahan, Character

\begin{abstract}
Abstrak
Peran dan kompetensinya, guru yang kompeten akan lebih mampu menciptakan lingkungan belajar yang efektif dan lebih mampu dalam Pengelolaan Tindakan Kelas sehingga hasil belajar siswa berada pada tingkat yang optimal. Tujuan penelitian ini adalah untuk mengetahui pengaruh manajemen tindakan kelas terhadap hasil belajar bahasa Indonesia terhadap keterampilan menyimak cerita di SD Negeri 1 Kaobula. Metode yang digunakan dalam penelitian ini adalah deskriptif kuantitatif yang digunakan sebagai desain penelitian yang mendeskripsikan secara jelas dan jelas variabel penelitian dalam bentuk angka dan statistik. Populasi dalam penelitian ini adalah 24 siswa kelas V SD Negeri 1 Kaobula. Berdasarkan hasil penelitian dapat disimpulkan bahwa pengaruh antara variabel X (pengelolaan tindakan kelas) dan variabel Y (hasil belajar PKn) memiliki pengaruh yang kuat antara kedua variabel tersebut. Jika kita melihat besarnya rxy yang didapat yaitu: 0.620 ternyata berada diantara 0.40. 0.60. Dapat dikatakan bahwa korelasi antara variabel X dan variabel Y memiliki pengaruh yang relatif kuat. Dengan demikian, penulis dapat secara sederhana memberikan interpretasi dari rxy yaitu terdapat pengaruh positif yang signifikan antara variabel $X$ dan variabel $Y$.
\end{abstract}

Kata Kunci: Pendidikan, Muhammadiyahan, Karakter 


\section{INTRODUCTION}

Improving the quality of education will be achieved if the teaching and learning process by the teacher held in the classroom is truly effective and useful for achieving the expected knowledge, attitudes, and skills. Because basically, the teaching and learning process is the core of the overall education process, while the teaching and learning process is carried out in many formal activities in the classroom where the teacher is one of the important factors in determining the success of the teaching and learning process in the classroom. Therefore, teachers are required to be able to improve their roles and competencies, competent teachers will be more able to create an effective learning environment and will be more capable of Classroom Action Management so that student learning outcomes are at an optimal level.

Classroom Action Management not only excels in helping students foster cooperation, creative thinking, and developing social attitudes but can also increase interaction between teachers and students, students and students, as well as students with the environment. In this regard, Slavin stated that "In learning, students will find it easier to find and understand difficult concepts if they discuss these problems with their friends. Good Classroom Action Management is about creating a conducive learning environment, utilizing facilities by taking into account the needs of students both individually and as a group. Because the essence of the main purpose of learning activities is to provide guidance and services to students so that they are willing to participate in learning actively.

Good Classroom Action Management is about creating a conducive learning environment, utilizing facilities by taking into account the needs of students both individually and as a group. Because the essence of the main purpose of learning activities is to provide guidance and services to students so that they are willing to participate in learning actively. To attract students' interest in understanding the concepts covered in the curriculum, especially in Indonesian, the subject of Story Listening Skills for SD as a whole is not easy. According to Nasrun, in the education forum, it was stated that teachers are required to be able to own and use teaching media following the material to be presented, they are required to be able to use stimulant teaching methods to liven up the teaching atmosphere properly.

The teacher has a role in shaping the soul and character of students because the teacher is a figure of a leader. The teacher is an architectural figure who can shape the soul and character of students. The teacher has the power to shape and build the personality of students to become someone useful for religion, homeland, and nation. The teacher is in charge of preparing capable moral people who can be expected to build themselves up and build the nation and state. In a simple sense, a teacher is a person who provides knowledge to students. The main thing that teachers must pay attention to in overcoming symptoms and an atmosphere that is not conducive because a decrease in student motivation is a challenge for a teacher to be able to revive student learning motivation to achieve national education goals.

The role of the teacher in the teaching and learning process is as follows: (a) the teacher as a demonstrator, (b) the teacher as the class manager, (c) the teacher as a mediator and facilitator, and (d) the teacher as an evaluator. In the teaching and learning process, a teacher not only has the knowledge to give to students but is also required to be able to manage the students as a whole. Principles in student management:

1. Students must be treated as subjects and not objects, so they should be encouraged to participate in any planning and decision-making related to their activities. 
2. The condition of students is very diverse, both physical, ability, and intellectual, in terms of physical condition, intellectual ability, social, economic, interests, and so on. Therefore, a variety of activities are needed, so that each student has a vehicle to develop optimally.

3. Students will be motivated to learn if they enjoy what they are taught.

4. The development of student motivation does not only concern the cognitive domains but also the affective and psychomotor domains.

Classroom management at SD Negeri 1 Kaobula still needs an application in Classroom Action Management because considering the number of students in the school is increasing every year because the school is an educational institution that has to deliver students in developing all the potential that Noermanzah, et al. 2018. By looking at this context Classroom Action Management can be seen as a very important endeavor and must be given priority by a teacher in a variety of activities related to curriculum and student development. The effort made is by giving it to students to carry out creative and directed activities. The objectives of the Citizenship Education subject are to develop competencies to have the ability to think rationally, critically, and creatively, so that they can understand various citizenship discourses, have intellectual skills and skills to participate democratically and responsibly, have a good character and personality, following the norms. which applies in the life of society and the state.

Based on classroom observations, the researcher saw that the students' understanding of SD Negeri 1 Kaobula in learning Indonesian was still low. This can be seen from the average results of students' tests. Based on the above background, the researcher is interested in conducting research and raising the problem in a thesis with the title: "The Relationship of Classroom Action Management to Indonesian Language Learning Outcomes. The Subjects of Students' Story Listening Skills at SD Negeri 1 Kaobula".

Classroom action management is a conscious effort to plan, organize, actualize, and carry out supervision or supervision of programs and activities in the classroom so that the teaching and learning process can take place systematically, effectively, and efficiently, so that all potential students can be optimized "(Karwati 2014: 6)

The success of teaching a teacher is not only directly related to the teaching and learning process, for example, clear objectives, mastering the material, choosing the right method, using the right means, and evaluating the right one. Another thing that is not less important is the success of the teacher in preventing the behavior of students from disrupting the teaching and learning process, the physical condition of learning, and the ability to manage it. The teacher's ability to choose the right classroom action management strategy depends on his ability to analyze the classroom problems he faces. If he puts the strategy right, the teaching and learning process will be effective.

The Competency Standards for learning Indonesian in SD are the minimum qualifications of students that describe the mastery of language skills and a positive attitude towards the Indonesian language and literature. Based on these competency standards, the objectives that are expected to be achieved in learning Indonesian are so that students can:

1. Communicate effectively and efficiently following applicable ethics, both orally and in writing.

2. Respect and proud to use Indonesian as the language of unity and state language.

3. Understand Indonesian and can use it appropriately and effectively for various purposes. 
4. Using the Indonesian language to improve intellectual abilities, as well as emotional and social maturity.

Learning Indonesian in SD is a forum to develop students' abilities in using language, especially as a means of communication. Learning Indonesian can provide the basic language skills needed, and absorb the knowledge learned through language. Besides, learning Indonesian can also form a positive language attitude and provide a basis for enjoying and appreciating Indonesian literature following the situation and language objectives.

Listening to learning material presented in the form of this type of learning material will make students learn in two directions, namely learning on print media and audio-visual media that have been provided. This is expected to make students more active in exploring themselves. Besides, teachers have an important role to play as facilitators of students during learning. Meanwhile, stories as activities that have existed since time immemorial until now have several types and their benefits for students. Stories for children according to Musfiroh (2015: 69) can be categorized into three types, namely: folklore, modern fiction, and factual stories.

Learning to listen to stories is the material given at the end of learning drama. Usually listening to stories is done after going through story listening learning, listening to the material, looking for story elements, and the end of learning is assessing listening to stories. listening to children's stories is often considered difficult because of limited ideas. One of the reasons for this is the classroom action management used in learning to listen to stories which makes it easier for students to develop a framework and develop it according to their respective ideas and ideas.

\section{RESEARCH METHOD}

This research is a type of preexperimental research design with the method of one group pre-test-post-test design (Sugiyono, 2010: 74). In this design, one group of subjects is used, first measurement (pre-test), then carried out treatment (treatment), then measure again (post-test). Thus the results of treatment can be known to be more accurate because it can compare with the conditions before and after being treated. In this study, the sample was first given a pre-test class, then given treatment using classroom action management and after that given a post-test. Then analyzed whether there is an effect of using classroom action management and its effectiveness compared to using listening to students' stories.

The location of this research was conducted at the Kaobula Elementary School 1 Baubau City. Determination of the number of samples depends on the size of the population. If the population is less than 100 , it is recommended that all of them be sampled so that the study is a population study. The total population is less than 100 people, so the sample in this study is the total population of 24 students.

The method used in this study is a quantitative research method used as a research design that clearly and clearly describes the research variables in the form of numbers and statistics.

\section{RESULTS AND DISCUSSION Description of Class Action Management (Variable X)}

The success of teaching a teacher is not only directly related to the teaching and learning process, for example, clear objectives, mastering the material, choosing the right method, using the right means, and evaluating the right one. Another thing that is not less important is the success of the teacher in preventing the behavior of students from disrupting the teaching and learning process, the physical condition of learning, and the ability to manage it. After classroom action management, the authors conducted a final test to determine the success of classroom action management. In 
classroom action management, several principles must be considered as a prerequisite for creating an effective and efficient learning model.

Based on these standard criteria, the research determines the level of success criteria for the action in this study. It can be seen from the classroom action management for students individually and classically for each respondent showing the level of classroom action management values because the student scores are only around 69.16 with a weighted score above that is equal to 1660 by using the formula, namely: the weight score divided by the number of samples to get that value. The pre-cycle frequency and percentage can be seen in the table below:

Table 1 Percentage of Classroom Action Management (Variable X)

\begin{tabular}{|c|c|c|c|c|}
\hline No. & Category & Score & Frequensy & Percentage \\
\hline 1. & Very good & $>90$ & - & - \\
\hline 2. & Good & $80-90$ & 10 & 41,67 \\
\hline 3. & Enough & $60-70$ & 5 & 20,84 \\
\hline 4. & Less & $40-50$ & 7 & 29,17 \\
\hline \multicolumn{3}{|c|}{ Amount } & 24 & 100 \\
\hline
\end{tabular}

From the data on student scores at the classroom action management stage (Variable $\mathrm{X}$ ) above, the researcher can obtain classical classroom action management data as follows: that the percentage results that reach a value $>90$ in the very good category do not exist, then the student's score that reaches the grade. 80-90 with good categories as many as 10 students or $41.67 \%$, then the scores of students who got a score of 60-70 in the sufficient category were 5 respondents or $20.84 \%$ and the scores of students who got a score of 40-
50 in the category were less as many as 7 students or $29.17 \%$.

Based on classroom action management in the learning process which is very urgent to be done by a teacher is to seek or create good teaching and learning conditions. With good learning conditions, it is hoped that the teaching and learning process will take place well too. A good learning process will minimize the possibility of failures and mistakes in learning. Therefore a teacher needs to have the ability to create good teaching and learning conditions and to achieve optimal levels of effectiveness.

\section{Description of Story Listening Skills (Variable Y)}

Based on the results of learning Indonesian in the material of Story Listening Skills for grade $\mathrm{V}$ students, the researcher conducted a targeted learning process. After teaching and learning activities, the researcher conducted a final test as an observation to determine the level of success of Indonesian language learning outcomes in Story Listening Skills material.

Based on these standard criteria, the research determines the level of success criteria for the action in this study seen from the results of learning Indonesian in the material of Story Listening Skills in grade V SD Negeri 1 Kaobula individually and classically for each respondent indicating the level of value of Indonesian learning outcomes in Listening Skills material. The story is because the student's score is only around 74.59 with the weighted score above that is 1790 by using the formula, namely: the weight score divided by the number of samples to get that value The presentation of the percentage of students, namely:

Table 2 Percentage of Indonesian Language Learning Outcomes on Story Listening Skills (Variable Y) 


\begin{tabular}{|c|c|c|c|c|}
\hline No. & Category & Percentage & Frequency & Score Range \\
\hline 1. & Very good & $>90$ & 1 & $4,17 \%$ \\
\hline 2. & Good & $80-90$ & 12 & 50 \\
\hline 3. & Enough & $60-70$ & 11 & 45,84 \\
\hline 4 & Less & $40-50$ & - & - \\
\hline \multicolumn{3}{|c|}{ Amount } & 24 & 100 \\
\hline
\end{tabular}

From the data on student scores on the Indonesian learning outcomes of Story Listening Skills material, the researcher can obtain data on student learning completeness classically as follows: that the percentage results that reach a value> 90 in the very good category are 1 student or $4.17 \%$, then the value 12 students score $80-90$ in either category or $50 \%$, then the students who score 60-70 in the sufficient category are 11 respondents or $45.84 \%$ and the students who score 40-50 are in the poor category. students who get these grades.

\section{Hypothesis testing}

Based on the results of the research above shows that the average value of classroom action management (Variable X) is 69.16 with a score of 1660 , and the average value of learning outcomes in Indonesian for Story Listening Skills (Variable Y) is 74.59 with a weighted score 1790. After knowing the average value of all influences, the researchers analyzed the validity, reliability, and hypothesis using the SPSS 19.0 program with a level of $\alpha=0.5$. The results of the study were conducted using the SPSS 16.0 program. It is known that the magnitude of the influence between classroom action management (simultaneously) on Indonesian learning outcomes of Story Listening Skills material calculated by the correlation coefficient is 0.74 , this indicates a moderate relationship.

The results of submitting a hypothesis between $\mathrm{h} 0$ and $\mathrm{h} 1$ if the count is greater than stable at the level of influence $\alpha$ $=0.5$, then $\mathrm{h} 0$ is accepted and $\mathrm{h} 1$ is rejected, while the account is smaller than $t$ table at the level of influence $\alpha=0.5$, so $\mathrm{h} 0$ is rejected and $\mathrm{h} 1$ is accepted.

That $t$ count $(4.529)<t$ table $(0.575)$ $=\mathrm{Ho}$ is rejected, $\mathrm{Ha}$ is accepted based on the results of the t-test hypothesis with the results of $t$ count $(4.529)<t$ table $(0.575)$, namely $\mathrm{Ho}$ is rejected and $\mathrm{Ha}$ is accepted. So the researcher can conclude that between (Ho) there is no effect of classroom action management $(\mathrm{X})$ on Indonesian learning outcomes, the material for Story Listening Skills (Y) is rejected, while (Hi) There is an effect of classroom action management $(\mathrm{X})$ on learning outcomes In Indonesian, the story listening skills (Y) was accepted. Meaning: there is an effect of classroom action management on Indonesian language learning outcomes in Story Listening Skills at SD Negeri 1 Kaobula.

\section{The Influence of Variable $X$ and Variable $Y$}

To determine the effect of variable $\mathrm{X}$ (classroom action management) and variable Y (learning outcomes of Indonesian language learning skills in listening to stories), the authors used the productmoment formula by entering the data obtained. From the above calculations, it turns out that the value of the test value of the effect of classroom action management on Indonesian learning outcomes in the subject of Story Listening Skills at SD Negeri 1 Kaobula is 0.74 . 0, 74. If you pay attention, then the influence index number that has been obtained is positive. This means that there is a strong influence between the variable $\mathrm{X}$ (classroom action management) and the $\mathrm{Y}$ variable (the results of learning Indonesian Language Listening Skills material). There is a strong influence between the two variables. If we look at the amount of oxy obtained, namely: 0.74, it turns out to be between 0.70. 0.90. It can be stated that the influence between variable $\mathrm{X}$ and variable $\mathrm{Y}$ is the influence that is classified as strong or high. Thus, the writer can simply give an interpretation of the proxy, namely that there is no significant 
positive effect between variable $\mathrm{X}$ and variable Y.

\section{CLOSING}

Based on this, it is concluded that the average value of classroom action management (Variable $\mathrm{X}$ ) is 69.16 with a score of 1660 , and the average value of learning outcomes in Indonesian for Story Listening Skills (Variable Y) is 74.59 with a weighted score. 1790. After knowing the average value of all effects, the researchers analyzed the validity, reliability, and hypothesis using the SPSS 16.0 program with a level of $\alpha=0.5$. The results of the study were conducted using the SPSS 16.0 program. It is known that the t-table is 0.620 , that the magnitude of the influence between classroom action management (simultaneously) on Indonesian learning outcomes of Story Listening Skills material calculated with the correlation coefficient is 0.620 , this indicates a moderate relationship. That $t$ count $(4,529)<t$ table $(0,620)=$ Ho is rejected, $\mathrm{Ha}$ is accepted based on the results of the t-test hypothesis with the results of $t$ count $(4.529)<t$ table $(0,620)$, namely Ho is rejected and $\mathrm{Ha}$ is accepted. So the researcher can conclude that between (Ho) there is no effect of classroom action management $(\mathrm{X})$ on Indonesian learning outcomes, the material for Story Listening Skills (Y) is rejected, while (Hi) There is an effect of classroom action management (X) on learning outcomes In Indonesian, the story listening skills (Y) was accepted. Meaning: there is an effect of classroom action management on Indonesian language learning outcomes in Story Listening Skills at SD Negeri 1 Kaobula.

\section{BIBLIOGRAPHY}

Aeni, N., Jabu, B., Rahman, M. A., Ismail, H., \& Bin-Tahir, S. Z. (2018). The Students' Needs in Maritime English Class at Ami Aipi Makassar, Indonesia. Journal of Language Teaching and Research,9(6), 1284-1292.
Aeni, N., \& Panggua, S. (2017, July). A classroom action research at the second year students of indonesian maritime academy aipi makassar. In International Conference on Education, Science, Art and Technology (pp. 131-142).

Amri, M., Tahir, S. Z. A. B., \& Ahmad, S. (2017). The implementation of Islamic teaching in multiculturalism society: A case study at pesantren schools in Indonesia. Asian Social Science, 13(6), 125.

Amri, M., Afifuddin, A., \& Bin-Tahir, S. Z. (2018). Religious Pluralism of the Indonesian Traditional Islamic Education Institutions. The Journal of Social Sciences Research, 4(12), 446-450.

Arsyad, U., Putranto, B., Aeni, N., Isnan, W., \& Hasnawir, H. (2019). Analysis of biogeophysics characteristics and discharge of Lompo Riaja Atas river and Lompo Riaja Bawah river, Ralla sub watershed. Jurnal Penelitian Kehutanan Wallacea,8(1), 2738.

Bin Tahir, S. Z. (2017). Multilingual teaching and learning at Pesantren Schools in Indonesia. Asian EFL Journal, 89, 74-94.

Bin-Tahir, S. Z., Bugis, R., \& Tasiana, R. (2017). Intercultural Communication of a Multicultural Family in Buru Regency. Lingual: Journal of Language and Culture, 4(2), 8-8.

Bin-Tahir, S. Z., Atmowardoyo, H., Dollah, S., \& Rinantanti, Y. (2017). Multilingual learning program: pesantren students' perceptions of the multilingual simultaneous-sequential model. JELE (Journal Of English Language and Education), 3(2), 44-53.

Bin-Tahir, S. Z., Suriaman, A., Hanapi, H., Iye, R., \& Umanailo, M. C. B. (2020). Development of Buru Local Language Conversation Material Based on the CommunicativeInteractive Approach for Elementary School Students. Solid State Technology, 63(2s).

Bin-Tahir, S., Hanapi, H., Mufidah, N., Rahman, A., \& Tuharea, V. U. (2019). Revitalizing The Maluku Local Language In Multilingual Learning Model. INTERNATIONAL JOURNAL OF SCIENTIFIC \& TECHNOLOGY RESEARCH, 8(10).

Bin-Tahir, S. Z., Atmowardoyo, H., Dollah, S., Rinantanti, Y., \& Suriaman, A. (2018). MULTILINGUAL AND MONOMULTILINGUAL STUDENTS'PERFORMANCE IN 
ENGLISH SPEAKING. Journal of Advanced English Studies, 1(2), 32-38.

Bin-Tahir, S. Z., Hanapi Hanapi, I. H., \& Suriaman, A. (2020). Avoiding Maluku Local Languages Death Through Embedded Multilingual Learning Model: Menghindari Kematian Bahasa Daerah Maluku melalui Model Pembelajaran Embedded Multilingual. Uniqbu Journal of Social Sciences, 1(1), 53-60.

Bin-Tahir, S. Z. (2015). The Power of Love: The Role of Boyfriend in English Language Acquisition.

Bin-Tahir, S. Z., Suriaman, A., \& Rinantanti, Y. (2019). Designing English Syllabus for Multilingual Students at Pesantren Schools. Asian EFL Journal, 23(3.3), 5-27.

Candrasari, R., Fadhillah, N., Praza, R., \& Desiariawati, N. (2018). An Analysis of Culture Value in Adat Bak Poe Teumeureuhom, Hukom Bak Syiah Kuala, qanun Bak Putro Phang, Reusam Bak Binatara. Indian Journal of Public Health Research \& Development, 9(12).

Djunaidi, F. G., Azwan, A. Y. T., Iye, R., \& bin Tahir, S. Z. Decks Range Gola Village Community Begun District Buton District North.

Fadhillah, N., Lubis, M. H., Sinar, T. S., \& Setia, E. (2019). Translation strategies used in Indonesian translation of Acehnese poem "Munajat Perempuan Sufi Aceh Pocut di Beutong.". International Journal of Innovation, Creativity and Change, 9(4), 172-182.

Khalsiah, R., Fadhillah, N., Praza, R., \& Desiariawati, N. (2018). An Analysis of Culture Value in Adat Bak Poe Teumeureuhom, Hukom Bak Syiah Kuala, qanun Bak Putro Phang, Reusam Bak Binatara. Indian Journal of Public Health, 9(12).

Lubis, M. H., \& Fadhillah, N. (2020). LOOKING FOR TRANSLATION OF MEANING OF WORDS QALA IN MATAN ARBA IN HADITH. Talent Development \& Excellence, 12(1).

Maulina, M. (2019, April). Gender differences in language development, acquisition, comprehension, and production. In PROCEEDINGS OF THE 65th TEFLIN INTERNATIONAL CONFERENCE (Vol. 65, No. 01).

Maulina, M. (2015). The Correlation Among Gender, Languange Learning Strategies, and
English Achievment of English Departement Students of Tarbiyah Faculty. Ethical Lingua: Journal of Language Teaching and Literature, 2(1), 27-41.

Maulina, M., \& Rusli, T. I. (2019). Pre-Service Teachers Performance in Implementing Teaching Methods at TEFL Class. Klasikal: Journal of Education, Language Teaching and Science, 1(1), 19-26.

Mufidah, N., Firdaus, U. Z., \& Tahir, S. Z. B. (2018). Model Pengayaan Tutor Bahasa: Studi pre-learning pada Shabahul Lughoh di Ma'had Sunan Ampel Al Aly. Jurnal AtTa'dib Vol, 13(2).

Nadilla, T., Ulfah, A. K., Hayati, H., Midesia, S., \& Puspita, D. (2019, November). The Effect Of Leverage And Earning Per Share On Earning Management (A Study Of Companies Listed In Indonesia Stock Exchange). In ICASI 2019: Proceedings of The 2nd International Conference On Advance And Scientific Innovation, ICASI 2019, 18 July, Banda Aceh, Indonesia (p. 164). European Alliance for Innovation.

Nurlaelah, N., \& Sakkir, G. (2020). Model Pembelajaran Respons Verbal dalam Kemampuan Berbicara. Edumaspul: Jurnal Pendidikan, 4(1), 113-122.

Rinantanti, Y., Bin-Tahir, S. Z., \& Suriaman, A. (2019). The Impact of EFL Senior High School Teachers' Performance in Papua, Indonesia toward the Students' English Learning Achievement. Asian EFL Journal, 23(3.3), 431-447.

Sakkir, G. (2020). The Effectiveness of Pictures In Enhance Writing Skill of Senior High School Students. Interference: Journal of Language, Literature, and Linguistics, 1(1).

Susiati, S., Masniati, A., \& Iye, R. (2021). Kearifan Lokal Dalam Perilaku Sosial Remaja Di Desa Waimiting Kabupaten Buru. Sang Pencerah: Jurnal Ilmiah Universitas Muhammadiyah Buton, 7(1), 8-23.

Sofie, samsudiin, Iye, R., Tenriawali, A. Y., \& Susiati, S. (2021). IDEOLOGI PRANGGAPAN PAMFLET SOSIALISASI PELESTARIAN LINGKUNGAN DI KABUPATEN BURU. BAHTERA: Jurnal Pendidikan Bahasa Dan Sastra, 20(1), 7283. https://doi.org/10.21009/bahtera.201.07

Suriaman, A., Bin-Tahir, S. Z., \& Usman, S. (2019). Designing Web-Based English Listening Instruction: An Analysis of 
Indonesian University Student's Needs. Asian EFL Journl. Vol. 23 (3.3), 28-40.

Saidna Z, B. T., Haryanto, A., Syarifuddin, D., \& Yulini, R. (2017). Multilingual Instructional Model of Pesantren Schools in Indonesia. Journal of Language Teaching and Research, 8(6), 1210-1216.

Sakkir, G., \& Dollah, S. (2019). Measuring students' writing skills using Facebook group application in EFL context. International Journal of Humanities and Innovation (IJHI), 2(3), 6974.

Tahir, S. Z. B., Atmowardoyo, H., \& Dollah, S. (2018). BELAJAR BERBICARA MULTIBAHASA UNTUK SANTRI PESANTREN. Yogyakarta, Deepublish.

TAHIR, S. Z. A. B. (2017). Pengembangan Materi Multibahasa untuk Siswa Pesantren (Doctoral dissertation, Pascasarjana).

Tahir, S. Z. B. (2015). Multilingual Teaching And Learning At Pesantren. 14 Asian EFL Journal Conference.

Tahir, S. Z. A. B. (2017). Pengembangan Materi Multibahasa untuk Siswa Pesantren (Unpublish Doctoral dissertation, Pascasarjana). Universitas Negeri Makassar.

Tahir, S. Z. B., \& Buru, D. U. I. (2012). Humor in "Bukan Empat Mata" Talk Show. Jurnal JUPITER, 5(4), 68-74.

Tuharea, V. U., Tahir, S. Z. B., Ami, I. S. O., \& Rahman, A. (2020). Buru Language Conservation Through Sustainable Mulok Learning In Buru Regency:(Konservasi Bahasa Buru melalui Pembelajaran Mulok Berkelanjutan di Kabupaten Buru). Uniqbu Journal of Social Sciences, 1(2), 49-55.

Ulfah, A. K. (2014). Implementasi Good Corporate Governance Dalam Meningkatkan Kualitas Pelayanan Pada Pt PLN Wilayah Aceh. Jurnal Administrasi Akuntansi: Program Pascasarjana Unsyiah, 3(3).

Ulfah, A. K. (2018). KINERJA PERSONIL PEMAKAI SISTEM INFORMASI AKUNTANSI SETELAH PELATIHAN SISTEM INFORMASI AKUNTANSI PADA POLDA ACEH. Jurnal Bis-A: Jurnal Bisnis Administrasi, 7(2), 40-46.

Umar, A., Madani, M., Farida, U., Yusriadi, Y., Tamsa, H., Yahya, M., ... \& Misnawati, M. (2019). One-Stop Service Policy as a Bureaucratic Reform in Indonesia. Academy of Strategic Management Journal, 18(2), 112.

Umanailo, M. C. B., Bin-Tahir, S. Z., Mukaddar, M., Kubangun, H., Hamiru, H., Sangadji, M. F., ... \& Yusuf, S. (2018). Economics And Survival Moral Strategies Of The Upland Rice Farmers. In International Conference on Life, Innovation Change and Knowledge (Vol. 1, No. 1).

Wahyuningsih, T., Bugis, M., \& Bin-Tahir, S. Z. (2019). Analysis of the Inequality on Interregional and Inter-time Income Distribution in Indonesia. The Journal of Social Sciences Research, 5(1), 1-8.

Wargadinata, W., Maimunah, I., Tahir, S. Z. B., \& Umanailo, M. (2020). Arabic creative and participative learning: in search of a new way of language learning by "El Jidal Reborn" youth community in Malang. International Journal of Advanced Science and Technology, 2(8s), 4319-4332.

Wijayanto, A. (2021). BUNGA RAMPAI Kolaborasi Multidisiplin Ilmu Dalam Menghadapi Tantangan di Era New Normal.

Yulismayanti, H., Iye, R., \& Susiati, S. Z. B. T. (2020). VARIATIVE METHOD IN IMPROVING STUDENT LEARNING MOTIVATION IN PANDEMIC COVID-19 SITUATIONS. Journal of Critical Reviews, 7(5), 1584-1595.

Yusriadi, Y., Bin-Tahir, S. Z., Farida, U., Sakkir, G., \& Akbar, Z. (2019). Community Perception in the Use of" Songkok Recca" Hats based on Social Stratification. Anthropos: Jurnal Antropologi Sosial dan Budaya (Journal of Social and Cultural Anthropology), 5(1), 31-39.

Yusriadi, Y., bin Tahir, S. Z., Awaluddin, M., \& Misnawati, M. (2020). Pengentasan Kemiskinan melalui Socialpreneur. Wikrama Parahita: Jurnal Pengabdian Masyarakat, 4(2), 115-120. 